\title{
An investigation into the delivery of goods to the city centre of Liège
}

\author{
W. Debauche \\ Mobility Department, Belgian Road Research Centre, Belgium
}

\begin{abstract}
The centre of Liège ranks among the most dynamic and attractive city centres of Belgium. Its vast pedestrian precinct and variety of stores make it one of the most popular shopping areas in our country.

In order to retain a lively shopping area with high-quality activities and to create an attractive environment for short or longer stays, efficient handling of the massive flows of goods to and from the shops located at the city centre is of paramount importance.

However, urban freight transport activities have a major impact on the environment (pollutant and noise emissions, visual pollution, road safety, energy consumption, etc.) and, consequently, on the quality of life in cities.

So far, little attention has been paid to the organization of urban freight transport. Freight transport is often forgotten in documents for local town and country planning or for transport planning, particularly in local travel plans (LTP).

To bridge this gap, the city of Liège entrusted the engineering firm ISIS with an expert investigation into the logistic activities at the city centre. This investigation was conducted in close cooperation with the Mobility Department of the Belgian Road Research Centre and aimed mainly at a better understanding of local freight transport, especially through:

- the definition of a typology of the problems of freight transport, depending on the commercial activities along a specific road or in a specific sector;

- $\quad$ the development of a planning procedure for massive goods flows (both supply and collection) in the shopping area.
\end{abstract}

Keywords: case study, urban freight logistic, mobility planning, survey. 


\section{Methodology}

Apart from a description of the state of the art and of the Belgian legislation in the field of movements and parking of delivery vehicles in cities, the investigation comprised three different types of survey to gain a better insight into the problems related to deliveries to the city centre of Liège.

Field observation of delivery behaviour between 7 a.m. and 2 p.m. in the geographic areas under study. The roads to be observed were cut into sections of an average length of 60 to $120 \mathrm{~m}$. In each section one surveyor observed of all traffic movements. For each movement (even if not related to a delivery) the surveyor recorded the following information:

- arrival time (minute), type of vehicle (bicycle, motor bike, private car, courier, van, heavy vehicle);

- place where the vehicle was parked (traffic lane, bus lane, footway, driveway, other part of the road);

- $\quad$ obstruction caused (to pedestrians or to other road users);

- departure time (in minutes).

A rapid survey through face-to-face interviews with over three hundred deliverers at the place of delivery. In addition to the data collected in the abovementioned observation, the following information was recorded:

- type of vehicle;

- place of delivery;

- arrival time;

- packaging of the delivered goods;

- $\quad$ handling device, if needed;

- (difficulty of) access;

- parking;

- $\quad$ any conflicts and hazards;

- duration;

- requested improvements: open question about the functionality of the regulations in force and future and immediate needs for improvement.

313 survey questionnaires were filled out for 943 movements, 516 of which were delivery-related.

A detailed survey through face-to-face interviews with one hundred and twenty shopkeepers. The questionnaire covered:

- the daily number of deliveries;

- the nature of the goods delivered on that specific day;

- the packaging of the delivered goods;

- the origin of the delivery;

- transport on own account or for hire and reward;

- $\quad$ a description of the logistic chain of order $\rightarrow$ delivery $\rightarrow$ reception;

- the storage of the goods after reception;

- $\quad$ any forwarding of the delivered goods;

- volumes;

- delivery constraints; 
- $\quad$ requested improvements, in general;

- $\quad$ expectations, especially during the implementation phase of the LTP.

120 questionnaires were filled out for a total of 1,700 shops at the inner city centre of Liège.

Although the sample was representative, a correction factor was applied to the aggregate surveys.

Additionally, about fifteen specific players in the field of freight transport were interviewed. Among them were:

- delegates of the local shopkeepers;

- the police superintendent;

- $\quad$ the manager of a hypermarket;

- the city centre manager (who is among other things in charge of the stewards).

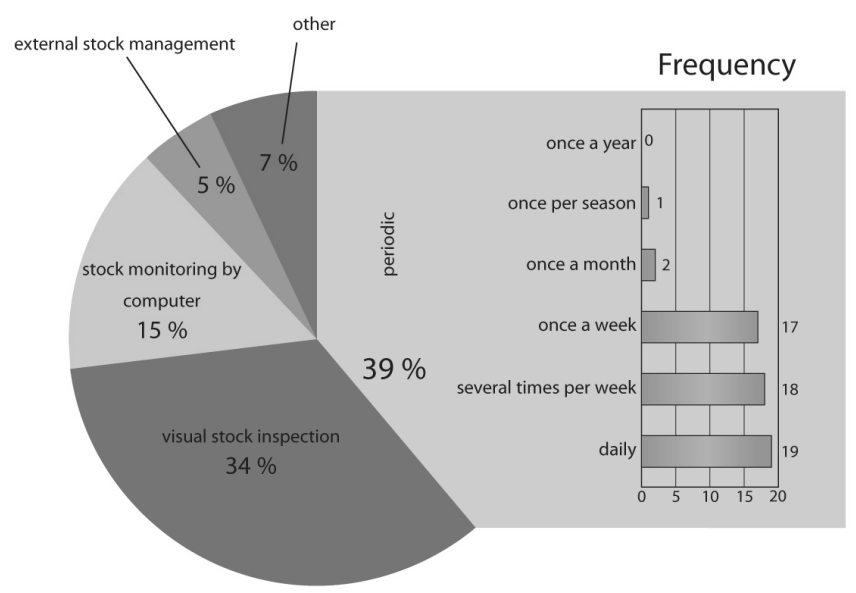

Figure 1: $\quad$ Process and frequency of the order.

\section{Analysis of the results}

The interviews and observations provided the basic elements for a detailed diagnosis of goods delivery to the city centre of Liège. Some of the information collected is presented hereafter at greater length.

\subsection{Delivery characteristics}

\subsubsection{Orders}

Over one third of the shopkeepers in Liège stick to the strong tradition of periodic orders. They place their orders several times per week.

Another third base their orders on visual stock inspection. This can be explained by the numerous clothes and shoe shops which display their whole stock on the shelves and do not hold a buffer stock in a back room. 


\subsubsection{Order lead time}

There is a tendency for premises to hold less stock on site. To cope with the reduction of stocks it is important that shoppers and companies receive goods as quickly as possible from the time they place an order so as to avoid disruption to the production process or lost sales.

Using computer-based reordering system could help companies to reduce the order lead time.

Figure 2 shows the order lead time which is generally very short (less than two days for $70 \%$ of the deliveries).

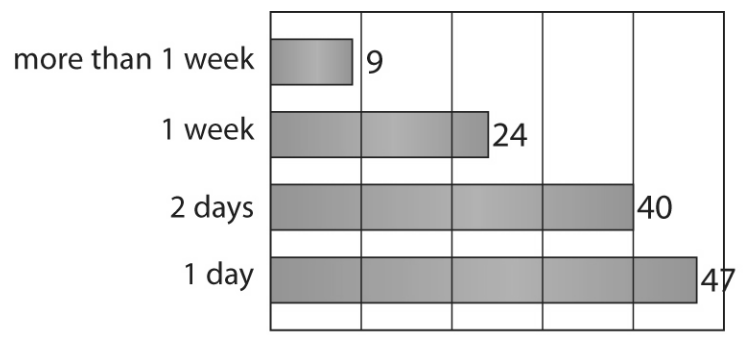

Figure 2: $\quad$ Order lead time.

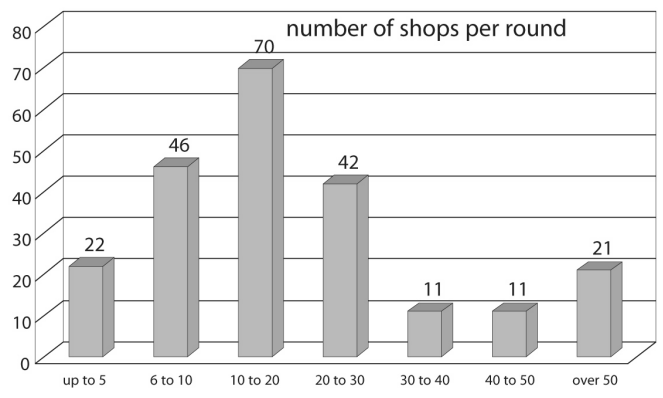

Figure 3: Number of shops delivered per multi-drop round.

\subsubsection{Packaging}

The great majority of the goods are delivered in parcels. This is logical, because shops work with small stocks - which means that small quantities have to be delivered). Moreover, the urban fabric is so dense that big lorries (allowing the delivery of larger quantities on pallets) cannot get through.

\subsubsection{Organization of deliveries}

$72 \%$ of the deliveries are made during a round. This figure is comparable to the results of investigations carried out in three French cities (Lyon, Bordeaux and Marseille). The average number of shopkeepers served during one round (about 
twenty) also corresponds to French findings. As the number of direct deliveries is quite small, organizing a round for these deliveries would not significantly reduce the number of vehicles.

\subsection{Analysis of the logistic chain}

\subsubsection{Delivery time}

From drivers' interviews, the main factors influencing the delivery time are:

- $\quad$ the period of which staff are on site at the premise to receive the goods. In general, premises only accept deliveries when staff are present on site to receive them (no practice of delivery without staff has been noticed in the survey);

- the potential access restriction rules in practice in the city centre (time restriction rules on vehicle access or on vehicle loading and unloading). For Liège, there is no legal restriction on the times at which it is permitted for goods vehicles to dwell at the roadsite but legal restrictions are for the access to the commercial pedestrianized zone in the city centre. This zone is only open to delivery from 8 am to $1 \mathrm{pm}$. But the system does not worked very well because a lack of enforcement.

In nearly one third of all cases, goods are delivered periodically at a fixed time (day and hour). This is consistent with the periodic ordering of goods.

In more than one third of all cases (the answer "varies" included) the deliverer decides himself upon the time of delivery and in one quarter of all cases the delivery is not even announced(!).

But from the interviews and surveys with transport companies and suppliers, it appears that receivers are not prepared to accept deliveries at time suitable to the transporter. In many cases they want to choose the time they receive their goods and it is always at the same time. This concentration of delivery time in a same period of the day could affect the round (no more the most geographically efficient routeing) and the vehicle load factor (Transport Studies Group, March 2000).

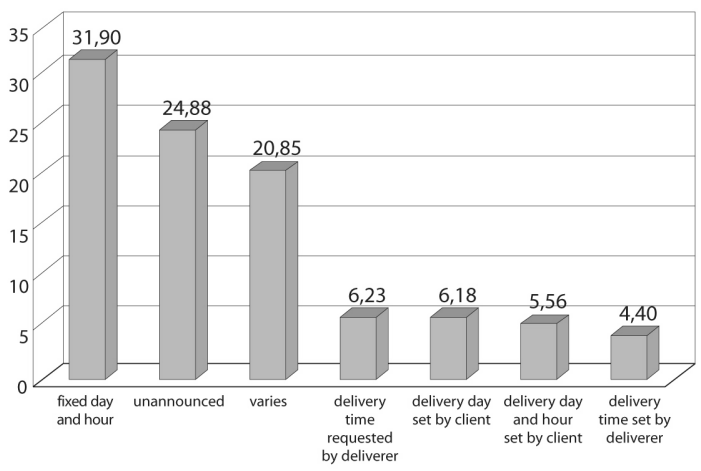

Figure 4: Delivery process. 
A majority of urban goods deliveries take place during the morning. Freight transport companies and their drivers point out the fact that more and more city centres have introduced loading/unloading time restrictions and so reduced the number of hours in the day available delivery work. That could lead to:

- $\quad$ increasing the number of goods vehicles during the permitted restricted period;

- $\quad$ increasing the vehicles fleet necessary to deliver;

- $\quad$ increasing veh-km necessary to carry out the deliveries;

- $\quad$ reduce the average time use by vehicle so increase the operational costs by vehicle.

Transporters suggest more cooperation and coordination between local public authorities before to implement such kind of restriction access rules.

\subsubsection{Type of vehicle}

Factors influencing the size and type of the goods vehicle operating deliveries in urban area are the following (Transport Studies Group, March 2000):

- the characteristic of the product;

- the quantity of the product;

- $\quad$ the number of receivers to be delivered to a round;

- $\quad$ the possibility of consolidation in the supply chain;

- the quantity to be delivered to each receiver;

- $\quad$ the possibility of products mixing on the vehicle;

- $\quad$ the potential access restriction rules at destination.

Heavy goods vehicles (HGVs) are vehicles with a mass of more than $3.5 \mathrm{t}$.

According to the field observations, the great majority (over $80 \%$ ) of vehicles used for deliveries are of smaller types, which is in keeping with the delivery characteristics reported above.

By way of comparison, the proportion found in France on a representative sample of 2,255 delivery vehicles was $50 \%$ under $3.5 \mathrm{t}$ and $50 \%$ of HGVs (in: Guide technique et juridique pour les livraisons en ville, éditions Celse, 1er trimestre 2004).

Deliveries in the city of Liège are made predominantly with small vehicles. Many interviewed shoppers and companies declare also to be delivered in a wide range of different-sized vehicles.

\subsubsection{Duration of deliveries}

The time taken to make a delivery depends on the premises and on the size of delivery. It is compounded by:

- the time on board parked vehicle organising paperwork

- $\quad$ the time on the parking site to prepare the unloading of the delivery;

- the time required to unload and go to the premise and come back to the vehicle.

In comparison with other cities, the duration of deliveries is rather long $(56 \%$ were completed in less than $15 \mathrm{~min}$ as opposed to $82 \%$ in other cities, viz. in France). However, this figure should be seen in the general perspective of most 
deliveries taking less than $5 \mathrm{~min}$. This may indicate a difficulty for the deliverer to find a parking place, or a tendency of the interviewees to overestimate durations.

\subsubsection{Wishes of deliverers}

Possible improvements suggested by the deliverers are mainly:

- $\quad$ the provision of more delivery areas;

- better reservation of existing areas.

One original suggestion was to issue deliverer's cards authorizing parking on reserved areas.

Several respondents have deplored the way the policy markers treat goods vehicles. All the rules they take for delivery operations and goods vehicles circulation are punitive instruments. There are no supportive instruments to facilitate the goods flows and the delivery operations. For them, goods vehicles should be treated as other road users (pedestrians, taxis, bus, ...) because there are not only produce negative impacts but also contribute to the economic and social development of the city.

\subsection{Analysis of road occupation by delivery vehicles}

\subsubsection{Data and indicators}

In addition to the logistic chains, the occupation of roads and delivery areas by heavy vehicles was analysed per geographic sector. The object was to investigate the adequacy, siting and layout of parking facilities for deliveries.

The following data was recorded:

- $\quad$ the length of delivery areas;

- $\quad$ the total number of movements (for delivery or other purposes, parking included) observed on a delivery area during the survey;

- $\quad$ the duration of each recorded movement.

These raw data were used to calculate the following indicators:

- the average duration of a movement, while discriminating between deliveries and other movements $=$ the cumulative duration of the movements divided by their total number;

- the time a delivery area is occupied by vehicles other than delivery vehicles $=$ the cumulative parking time of "non-delivery" vehicles on delivery areas, calculated per area. In this calculation it was considered that a delivery area was not fully occupied ("squatted") when a single "non-delivery" vehicle was parked on it - assuming by default that this vehicle was parked in the best possible way;

- the time a delivery area is used for deliveries, calculated per area in an urban environment. In this calculation it was considered that any delivery takes up the whole area;

- $\quad$ and, finally, the time a delivery area is entirely free = the seven hours of observation time minus the two times defined above, calculated per area. 
The various road sections were then categorized to allow the development in consultation with the local shopkeepers - of concrete proposals for the siting and layout of parking facilities for deliveries.

\section{Potential solutions}

The use of lorries to deliver goods to town centre destination has led to demands from local actors such as shoppers, local residents and several lobbies for alternative distribution practices which could reduce inner city vehicle bad effects such as pollutant emissions but also noise and congestion.

Potential solutions for the specific case of Liège city centre have been listed. These potential solutions could be categorized as following:

- Infrastructure and physical planning;

- Measures concerning the vehicle and their use;

- Parking policies

- Logistics;

- Time and access restriction

- Communication and signalisation.

\subsection{Proposals}

Based on the quantification of the inbound and outbound flows of goods and on the interactions between them, recommendations were made for:

- the pedestrian precinct (regulation of delivery hours, traffic, closure, access control);

- the delivery areas surveyed (geographic distribution, type of facility, layout, etc.);

- the possible development, in the medium term, of other tools to allow easier freight transport and goods deliveries (accessibility, distribution centres outside the city centre, fiscal measures, etc.);

- $\quad$ the application of the methodology presented above to other sectors of the city;

- the contents of a promotion and information campaign for the organization of deliveries to the city centre.

The table below reviews the proposed priority actions.

\section{Conclusions}

Although urban freight transport is essential to the economic and social development of a city, and a fundamental component of mobility, it has long been forgotten by transport researchers and urban planners. The investigation conducted into deliveries to the city centre of Liège shows the growing interest of decision-makers to - finally - integrate this component in their urban mobility strategy. 
Table 1: Actions plan.

\begin{tabular}{|c|c|c|}
\hline $\begin{array}{l}\text { Highlight } \\
\text { action }\end{array}$ & $\begin{array}{c}\text { Concurrent } \\
\text { principal action }\end{array}$ & $\begin{array}{c}\text { Concurrent } \\
\text { supporting action }\end{array}$ \\
\hline $\begin{array}{l}\text { Information campaign on } \\
\text { the investigation } \\
\text { conducted into freight } \\
\text { transport and goods } \\
\text { deliveries within the city. }\end{array}$ & $\begin{array}{l}\text { Appointment of a "Mister } \\
\text { Freight Transport". }\end{array}$ & $\begin{array}{l}\text { Renovation and } \\
\text { harmonization of road } \\
\text { markings in delivery } \\
\text { areas. }\end{array}$ \\
\hline $\begin{array}{l}\text { Thorough investigation } \\
\text { into, and consultation on, } \\
\text { the management of the } \\
\text { pedestrian precinct (one- } \\
\text { way traffic, accessibility, } \\
\text { etc.). }\end{array}$ & $\begin{array}{l}\text { Treatment of delivery } \\
\text { areas at the perimeter of } \\
\text { the pedestrian precinct } \\
\text { ("Cathédrale" and } \\
\text { "Opéra") }\end{array}$ & $\begin{array}{l}\text { Information folders for } \\
\text { hauliers. } \\
\text { Provision of information } \\
\text { points for the } \\
\text { organization of urban } \\
\text { goods transport on the } \\
\text { main roads network. }\end{array}$ \\
\hline $\begin{array}{l}\text { Investigation into, and } \\
\text { consultation on, HGV } \\
\text { routes in Liège. }\end{array}$ & $\begin{array}{l}\text { Development of the } \\
\text { pedestrian precinct. } \\
\text { Treatment of the other } \\
\text { existing delivery areas } \\
\text { (resiting, removal, } \\
\text { enforcement). }\end{array}$ & $\begin{array}{l}\text { Provision of long-term } \\
\text { parking space for lorries, } \\
\text { e.g. using the park-and- } \\
\text { ride facilities at the fringe } \\
\text { of the city. }\end{array}$ \\
\hline $\begin{array}{l}\text { Setting regulations for } \\
\text { delivery hours and days } \\
\text { and establishing routes } \\
\text { for HGVs. }\end{array}$ & $\begin{array}{l}\text { HGV route signing. } \\
\text { Installation of a team to } \\
\text { enforce the regulations. }\end{array}$ & $\begin{array}{l}\text { Information to lorry } \\
\text { drivers on parking } \\
\text { facilities along the main } \\
\text { roads network. }\end{array}$ \\
\hline $\begin{array}{l}\text { Investigation into, and } \\
\text { construction of, new } \\
\text { delivery spaces (delivery } \\
\text { areas, urban logistic } \\
\text { centres, etc.). }\end{array}$ & $\begin{array}{l}\text { Development of public } \\
\text { spaces on the quays at the } \\
\text { "INNO". } \\
\text { Information to users and } \\
\text { subsequent enforcement } \\
\text { (fining). }\end{array}$ & $\begin{array}{l}\text { Amendment of the local } \\
\text { urban development } \\
\text { regulations to allow the } \\
\text { enforcement of private } \\
\text { delivery areas. }\end{array}$ \\
\hline
\end{tabular}

This investigation was innovative for Belgium in that some of the data was collected for the first time, and in that way (through field observations and through surveys among delivery personnel and shopkeepers).

At present, the goal should be to methodize the integration of freight transport in planning documents such as local travel plans (LTPs) and mobility agreements. 
Furthermore, it would be interesting to carry out similar studies in other city centres. This would make it possible to identify "invariables" and to characterize goods flows in urban areas, with a view to gaining a better understanding of the problem and developing more effective solutions.

\section{References}

[1] J. Allen, S. Anderson, M. Browne, P. Jones, "A framework for considering policies to encourage sustainable urban freight traffic and goods service flows", Transport Studies Group, March 2000.

[2] Prise en compte des marchandises dans les Plans de Déplacements urbains. CERTU (Centre d'Etudes sur les Réseaux de Transport, l'Urbanisme et les Constructions publiques), Lyon, 1998.

[3] L. Dablanc, P. Pecheur, "Transport de marchandises en ville. Que font nos voisins européens?", GART, Paris, 2000.

[4] L. Dablanc, "Guide technique et juridique pour les livraisons en ville", GART, Paris, 2004.

[5] D. Patier, "La logistique dans la ville",Celse, Paris, 2004.

[6] "Delivering the goods. 21st century challenges to urban goods transport", OECD, 2003.

[7] Urban goods transport. COST 321. Final report of the Action. European Commission, 1998. 